\title{
"Approaches to measuring resilience and their applicability to small retail business resilience"
}

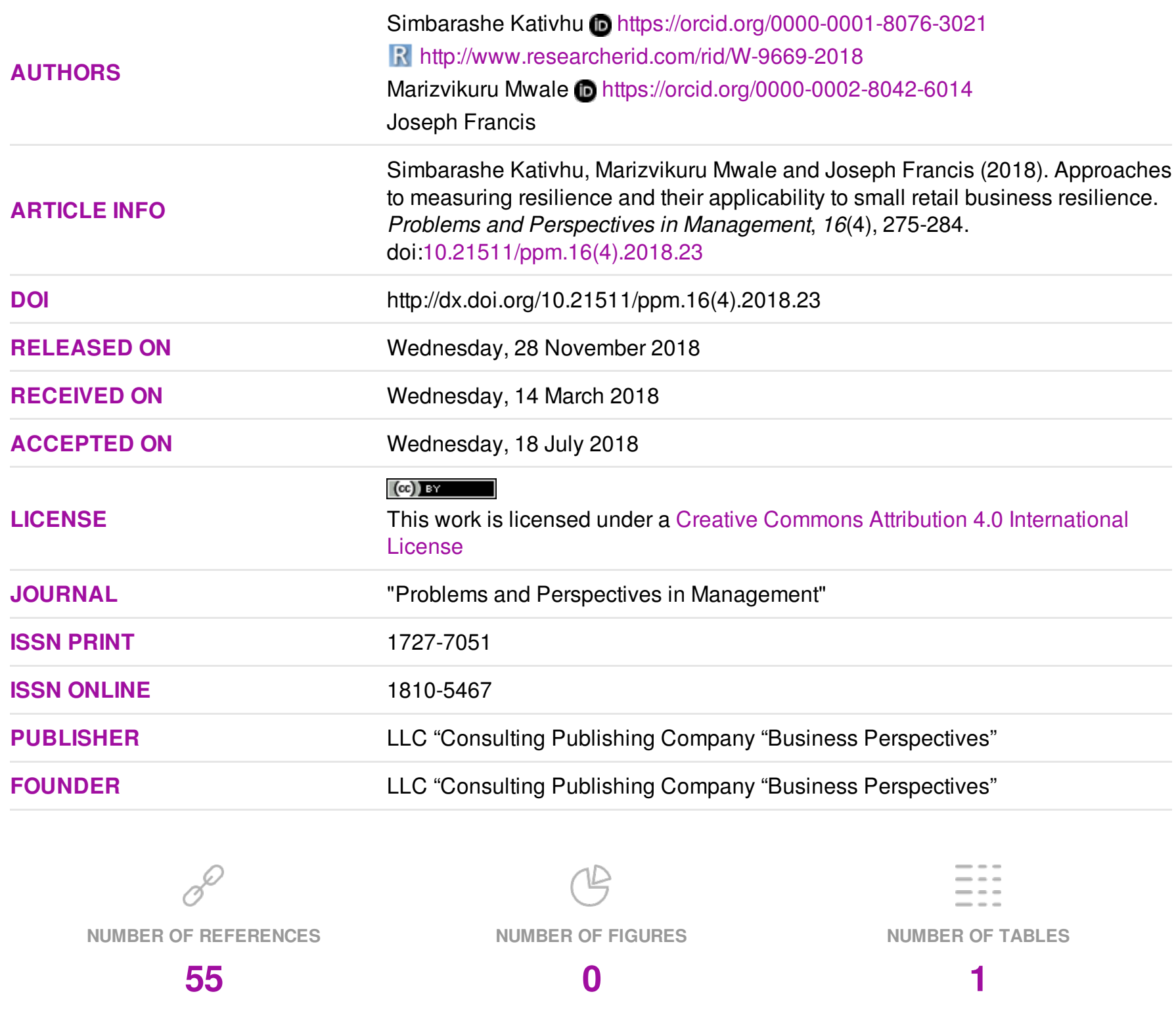

(c) The author(s) 2023. This publication is an open access article. 


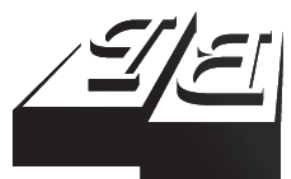

BUSINESS PERSPECTIVES

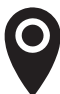

LLC "CPC "Business Perspectives" Hryhorii Skovoroda lane, 10, Sumy, 40022, Ukraine

www.businessperspectives.org

Received on: $14^{\text {th }}$ of March, 2018 Accepted on: $18^{\text {th }}$ of July, 2018

(C) Simbarashe Kativhu, Marizvikuru Mwale, Joseph Francis, 2018

Simbarashe Kativhu, Ph.D. in Rural Development, University of Venda, South Africa.

Marizvikuru Mwale, Doctor of Philosophy, University of Venda, South Africa.

Joseph Francis, Professor, University of Venda, South Africa.

\section{(c) (i)}

This is an Open Access article, distributed under the terms of the Creative Commons Attribution 4.0 International license, which permits unrestricted re-use, distribution, and reproduction in any medium, provided the original work is properly cited.
Simbarashe Kativhu (South Africa), Marizvikuru Mwale (South Africa),

Joseph Francis (South Africa)

\begin{abstract}
The resilience concept has attracted interest across many fields in the recent years. The interdisciplinary nature of the concept has led to the existence of numerous definitions, interpretations and measurement approaches. For this reason, there is no acceptable universal understanding of resilience across disciplines. Even though the concept is conceptualized differently in the small retail business field, scholars seem to commonly relate resilience to the ability of business to adapt to disruptions that threaten existence. However, resilience measuring has been a highly contested aspect in the sector. As such, neither key resilience attributes nor universally applicable criteria for resilience measuring exist in the small retail sector. At the same time, small retail businesses are increasingly exposed to direct and indirect threats that jeopardize their resilience prowess. Therefore, it is vital to develop approaches for assessing resilience levels and monitor changes over time. This paper critically examines current approaches to developing resilience measurement tools. Thereafter, it proposes the most applicable approach for developing performance measures of resilience for use in the small retail business sector. A review of key frameworks for resilience measuring within climate, community, livelihoods, organizational and business sectors was conducted. Frameworks and approaches for resilience measuring that has been in use in the past decade and half were selected. The main focus was on exploring methodological aspects, resilience attributes and variations in the interpretation of the resilience concept within different frameworks. It was revealed that the generic application of frameworks for resilience measuring in the small retail business sector is not appropriate. Thus, there is a need for developing contextualized frameworks to guide resilience measurement in the small retail sector.
\end{abstract}

\section{Keywords}

JEL Classification attributes, contextualization, measurement criteria, resilience, small retail business

\section{INTRODUCTION}

The small retail business resilience concept is increasingly gaining recognition from development agencies and researchers. One of the key aspects requiring attention is developing parameters for resilience measuring (Dalziel \& McManus, 2004; Sanchis \& Poler, 2014). The current turbulent environment in both world and local economies has, in general, enlightened the need for small business to be resilient. The need for developing resilient youth-run small retail businesses is more apparent in South Africa. Approximately 70\% of South African micro-businesses are concentrated in retailing (Ligthelm, 2006). Similarly, between 70 and $80 \%$ failure rates were reported in South Africa (Van Scheers, 2010). Charman (2012) adds that approximately $50 \%$ of new spaza shop entrants collapse within 5 years, strengthening resilience within the youth small retail business sector. Despite this situation, Sanchis and Poler (2014) lament the scarcity of literature on approaches to resilience measuring of small businesses in general. In 
particular, knowledge of approaches for measuring small retail business resilience is still limited (Erol et al., 2010). Consequently, there is no specific and universal criteria for measuring small retail business resilience. In the absence of guidelines for determining resilience drivers, development agents cannot make informed decisions about the most appropriate interventions. Conferring to this background, it becomes important to provide approaches that guide the measurement of small retail business resilience.

The multidisciplinary nature of the resilience concept brings the need for contextualizing its measurement approaches. This paper sought to establish general building blocks that can guide the development of approaches for measuring small retail business. Secondary data analysis of at least 9 major resilience frameworks that have been in use in the past decade and half was conducted. The review focused on assessing how different frameworks define resilience, its attributes and indicators. The paper provided a conceptualized approach for use in measuring small retail resilience based on insights from frameworks that are utilized in climate change, livelihoods, community, organizational and business fields. The following sections cover the overview of small retail businesses, definitions of resilience, and discussions on the existing approaches for measuring resilience. Contextual and methodological challenges for resilience measuring are also discussed. Lastly, the most applicable approach for use in the small retail business sector is provided.

\section{THEORETICAL BASIS}

\subsection{Overview of small retail businesses}

Small retail businesses development, particularly spaza shops, is part of the government's quest to build the rural economy in South Africa (Small Enterprise Development Agency: SEDA, 2007). Small retail businesses are defined as all activities involving buying and selling in small quantities. It encompasses activities such as hawking, vendors, spaza shops and tuck shops (Woodward et al., 2011). Within the broader framework of enterprise development, the South African government identified women and youth businesses as key cohorts that require support (Madzivhandila, 2014; Sanyal \& Hisani, 2015). High rates of unemployment and poverty among youth and women justify government preference. For instance, youth unemployment rate is reportedly higher than the average in the country at $50.7 \%$ for the 15 to 24 age group and $29.8 \%$ for the 25 to 34 age group (Rachidi, 2014). To tackle this problem, desperate rural and township dwellers start their own small retail businesses. The potential for small retail businesses to create jobs and reduce poverty prompts the need for strengthening resilience in the sector.

Despite the potential of small retail business to create jobs, their sustainability is at risk. For instance, approximately $46.4 \%$ of new small busi- nesses in UK have experienced high failure rates (Timmons \& Spinelli, 2009). In the United States of America, small retail businesses have declined to a mere one third (Muller et al., 2003). Byron (2003) also laments the decreasing number of village shops worldwide. Small retail business growth is also on the decline in most developing countries (ILO, 2006). Moreover, rural small retail businesses have a higher possibility of failing than their urban counterparts worldwide (Muller et al., 2003). In South Africa, despite wide range support, the growth and survival rates of small businesses are generally lower than expected. Along the same line of thinking, $75 \%$ of newly formed small businesses are unable to become sustainable (Fatoki \& Garwe, 2010). This attests to the lack of resilience and growth models for small businesses particularly in the country.

Intense global competition, rapid changes in technology, customer demands, and economic uncertainty generally threaten the resilience of small retailers (Demmer et al., 2011). In a broader context, internal and external vulnerability factors jeopardize the resilience of small retail businesses (Ehlers \& Lazenby, 2007; Van Scheers, 2010). Regulatory frameworks and access to finance are generally regarded as external threats, while internal shocks mainly cover characteristics of the entrepreneur (Dess, 1996; St-Jean, 2008; International Finance Corporation: IFC, 2013). However, studies in South Africa commonly gen- 
eralize threats to all small businesses without considering sectorial distinctions. This results in the application of generic resilience drivers in various interventions. In most cases, this has rendered interventions inadequate or fruitless. As such, interventions to strengthen small retail business resilience should be guided by a clear understanding of contextualized threats, as well as resilience drivers.

The kind of ownership also presents challenges in the small retail sector. Common ownership typologies include individual, family and cooperative ownership. In family business, succession planning mainly largely contributes to resilience (Egbu et al., 2005). Therefore, failure to pass on knowledge to the next generation often inhibits success in the sector (Levy et al., 2003). Knowledge retention also contributes to business success even in individually owned small retail businesses. In cooperative small retail business ventures, the ability to co-exist juxtapozes one another and brings harmony and success. This illustrates that resilience factors may differ based on the type of ownership. Variations in management, risk taking prowess and decision-making channels account for the distinctions in resilience factors across ventures. For this reason, the kind of small retail business ownership should be considered when measuring resilience.

Technological advancement also increases the vulnerability of the small retail sector. El Sawy and Pereira (2013) highlight that digital business is evolving at a fast pace driven by intense competition and rapid improvements in technology. Although technological advancement brings economic value, digital operation of small businesses such as small retail business is risky (Adshead, 2008). The velocity of exchange in digital business means competitive advantage is short-lived (El Sawy \& Pereira, 2013). In digital business, changes to strategic variables are rapid and unexpected as disruptions occur at any time from innovations (Burgelman \& Grove, 2007). Cyber security has also posed a serious threat to small retail enterprises in recent years. Given the challenges posed by technological advancement, there is a need to find ways of assessing the contribution of small retail business digital capabilities to resilience. This provides direction for the best possible resilience intervention in the sector.

\subsection{Small retail business resilience defined}

It is very difficult to measure resilience without knowing what has to be measured exactly. This is due to the fact that the resilience concept is defined variably in different context (Levine, 2014). In psychology, resilience is commonly perceived as the positive adaptive capacity of individuals experiencing adverse conditions (Kantur \& Say, 2015). Distinctively, ecologists commonly view resilience as the resistance and flexibility capacity of a system in order to attain sustainability (Kantur \& Say, 2015). Hamel and Valikangas (2003) define business resilience as the ability to dynamically reinvent business ideas and approaches as situations change. Similarly, Reinmoelle and Van Baardwijk (2003) describe resilience as the capacity of a business to self-renew over time through innovation. Sheffi and Rice (2005) demonstrate that flexibility as a core pillar of business resilience. Worth noting is the fact that scholars in the business field reject the equilibrium aspect, which is congruent in psychology and ecological studies. Instead, they content that businesses apply adaptive mechanisms to counteract the effects of disturbances and thereafter assume a different shape that allows sustainability.

Retail business resilience is broadly defined as the ability to sustainably adapt to changes and shocks that challenge stability (Replacis, 2011). Stelling (2011) highlights that retail resilience encompasses the ability to detect, prevent and handle disruptive challenges in a sustainable manner. Outstandingly, the ability of a business to respond and adapt to unexpected changes and disturbances that affect characterizes most retail resilience definitions (Erol et al., 2009). Notably, the above-mentioned definitions mainly relate to large retail businesses. Erol et al. (2010) also argue that, despite the broad definition of resilience in other fields, small retail resilience is scarcely understood. It is therefore important to contextualize the definition to small retail businesses. Small retail businesses differ from large retailers in that they are directly and indirectly affected by extreme events, yet they possess fewer resources to respond and retain resilience (Ingirige et al., 2008). Due to these distinctions, Levine et al. (2014) recommend that tools for resilience measuring cannot be developed unless 
there is a clear understanding of the aspect to be measured. Therefore, attempts to measure small retail business resilience should be informed by a clear understanding of the concept. The following section focuses on critically discussing various approaches to resilience measuring that are utilized in different fields. This assists in determining the most appropriate framework that can guide the development of resilience measuring approaches in the small retail sector.

\subsection{Overview of existing frameworks/approaches}

This subsection reviews frameworks and approaches to resilience measuring (Table 1).

Table 1. Existing frameworks/approaches to measuring resilience

\begin{tabular}{|c|c|}
\hline $\begin{array}{l}\text { Resilience measuring } \\
\text { framework/approach }\end{array}$ & Resilience attributes \\
\hline $\begin{array}{l}\text { DFID Building Resilience } \\
\text { and Adaptation to } \\
\text { Climate Extremes and } \\
\text { Disasters (BRACED) } \\
\text { projects (DFID, 2011) }\end{array}$ & $\begin{array}{l}\text { Anticipatory capacity, adaptive } \\
\text { capacity, absorptive capacity and } \\
\text { transformation ( } 3 \mathrm{As})\end{array}$ \\
\hline $\begin{array}{l}\text { Resilience Index } \\
\text { Measurement and } \\
\text { Analysis Model (RIMA) } \\
\text { by FAO (FAO, 2012) }\end{array}$ & $\begin{array}{l}\text { Physical dimensions: income } \\
\text { and food access; access to basic } \\
\text { services; assets; social safety nets; } \\
\text { enabling institutional environment; } \\
\text { natural environment; agricultural } \\
\text { practice/technology; capacity } \\
\text { dimensions: adaptive capacity; } \\
\text { sensitivity }\end{array}$ \\
\hline $\begin{array}{l}\text { Oxfam GB Multi- } \\
\text { Dimensional Approach } \\
\text { to Resilience Measuring } \\
\text { (Oxfam GB, 2013) }\end{array}$ & $\begin{array}{l}\text { Livelihood viability; innovation } \\
\text { potential; contingency resources } \\
\text { and support access; integrity of } \\
\text { natural and built environment; } \\
\text { social and institutional capability }\end{array}$ \\
\hline $\begin{array}{l}\text { USAID Measurement } \\
\text { Framework for } \\
\text { Community Resilience } \\
\text { (USAID, 2013) }\end{array}$ & $\begin{array}{l}\text { Income and food access; assets; } \\
\text { adaptive capacity; social capital } \\
\text { and safety nets; governance; } \\
\text { nutrition and health }\end{array}$ \\
\hline $\begin{array}{l}\text { The systems approach } \\
\text { to resilience measuring } \\
\text { (Dalziell \& McManus, } \\
\text { 2004) }\end{array}$ & $\begin{array}{l}\text { Interrelations organizational } \\
\text { components and stakeholders; } \\
\text { complex interactions }\end{array}$ \\
\hline $\begin{array}{l}\text { The continuous process } \\
\text { approach (Wreathall, } \\
\text { 2006; Haimes et al., } \\
\text { 2008) }\end{array}$ & $\begin{array}{l}\text { Preventive, protective, adaptive } \\
\text { and recovery functions and tasks }\end{array}$ \\
\hline $\begin{array}{l}\text { Resilience measuring } \\
\text { against the disruptive } \\
\text { event (Westrum, 2006) }\end{array}$ & $\begin{array}{l}\text { Threat detection, prevention and } \\
\text { adaption attributes }\end{array}$ \\
\hline $\begin{array}{l}\text { Livelihoods Change } \\
\text { Over Time Model (Vaitla } \\
\text { et al., 2012) }\end{array}$ & $\begin{array}{l}\text { Policies and institutions, extending } \\
\text { to measuring change in event of } \\
\text { shocks/acute crises }\end{array}$ \\
\hline $\begin{array}{l}\text { 3-D Resilience } \\
\text { Framework (Bene et al., } \\
\text { 2013) }\end{array}$ & $\begin{array}{l}\text { Absorptive, adaptive and } \\
\text { transformative capacities }\end{array}$ \\
\hline
\end{tabular}

Special focus was on the resilience attributes, as well as indicators underpinning each framework. Characteristic based methods such as Oxfam's MultiDimensional Approach attempts to identify reliable determinants of household and community level resilience that can be assessed prior to shocks occurring (Hughes \& Fuller, 2013; Oxfam GB, 2013; Sturgess, 2017). However, Frankenberger and Nelson (2013) argue that the approach fails to address whether the characteristics identified are actually relevant when a shock ultimately occurs. Furthermore, resilience is not static, hence, its determinants are constantly changing as the social economic and environmental landscapes within which households and communities operate also change (Bene \& Colleagues, 2012). Furthermore, most of the character-based approaches measure resilience against certain threshold, and in doing so reducing resilience into a single score. Levine (2014) argues that resilience assessment approaches must leave space for differences of opinion about the available alternative strategies. For this reason, characteristic measures of resilience should be treated as predictors of likelihood rather than its constituents. This argument provides insight into why the abovementioned approach cannot be applicable in measuring small retail businesses.

Approaches such as the Resilience Index Measurement and Analysis Model (RIMA) by FAO and the USAID Measurement Framework for Community Resilience allow households and communities to define resilience and develop indicators themselves. Resilience attributes for these approaches are informed by local realities. As a result, the approaches can objectively assess the resilience status of communities and households on issues such as food security and livelihoods. While such approaches are participatory and inclusive, their shortfall is that establishing contextualized characteristics requires indepth engagement of communities (Hughes \& Fuller, 2013). Thus, if in-depth engagement methodologies are not utilized, the reliability and objectivity of the outcomes is affected. UNDP (2014) also highlights that the specific nature of the approach also makes it difficult to compare the resilience levels of different groups. For small retail businesses, participatory approaches can help to establish objective attributes of resilience that are informed by practical realities if they are appropriately applied. However, the fact that the abovementioned attributes were obtained from a community resilience perspective renders them 
as appropriate for use in the small retail businesses unique context.

More so, the technical differences between various approaches generally relate to the choice of indicators/characteristics and the way they are weighted. Levine (2014) illustrated that most of the existing models choose generic characteristics of resilience based on judgment rather than empirical evidence or analysis of vulnerability. This is reflected by the lack of longitudinal studies for determining those characteristics. Contrary to the generic use of objective indicators and characteristics of resilience, Bene et al. (2016) argue that resilience comprises subjective elements rather than just tangible factors such as assets. This attests to the fact that reviewed frameworks all fall short in addressing subjective resilience. Subjective measures relate to individual self-assessment of their own household or business capacities to handle future events (Maxwell et al., 2015). These include individual risk perception, self-efficacy and aspirations. As such, subjective measures may provide a helpful bottom-up tool for capturing the voice of beneficiaries. Given these shortfalls in existing frameworks for measuring resilience, it is clear that their application to small retail businesses may not provide desired outcomes. Levine (2014) recognizes that no approach can ever meet resilience analytical needs in all fields. Thus, there is a need for developing smaller conceptual models that guide resilience measurement in specific fields such as the small retail business sector.

Apart from frameworks commonly applied in community, livelihoods and climate change resilience, approaches in organizational resilience are gaining recognition. One of the frameworks is the systems approach that takes a comprehensive view of the organization rather than focusing on selected elements. It stipulates that organizations are highly complex and thus understanding resilience requires more than just identifying causes and effects (Dalziell \& McManus, 2004). Dalziell and McManus (2004) further highlight that resilience is influenced by the different components and stakeholders in an organization that are interconnected by complex interactions. It is therefore difficult to determine the impact of a particular decision on the overall organization. Parallel to the aforementioned view, resilience is dynamic, and its levels are bound to fluctuate depending on the severity of the threat and the level of or- ganizations' preparedness to adapt and other related technicalities. In this regard, the systems approach can arguably be more useful in resilience measuring particularly in organizations where the internal and external environment is stable over longer periods.

Measuring small retail business resilience through the lens of organizational resilience approaches may not be possible due to the fact that small retail businesses are not complex and are normally run by one owner. Their main threats are resident in the local economic set up and the way individuals or groups address daily challenges. Some threats are covariate, while others are idiosyncratic within the same locality. Therefore, measuring small retail business resilience requires an in-depth understanding of the local economic landscape and the drivers of resilience for businesses in a particular geographical area. Levine (2014) concretizes this argument by emphasizing that resilience measuring must be underpinned by a clear understanding of the rationale of the people whose lives are being studied.

Wreathall (2006), Haimes et al. (2008) propose a continuous process approach, which is based on resilience capacities. They assume that resilience is a process that spans from pre-event to post-event recovery. The process includes the functions and task to prevent, protect, respond and recover. As a result, business resilience stems from a continuous process that includes planning for resilience, responding and adapting after threats. The approach identifies four attributes of resilience (prevent, protect, respond and recover) and assumes how they enable the construction of metrics for measuring resilience. Despite the relevance of this approach as a guide for measuring business resilience, it does not specify the significance of each attribute in relation to resilience levels. This may lead to the belief that all capacities are equally important for resilience and the failure of one attribute may compromise business sustainability. Again, the approach overlooked the significance of subjective resilience elements.

\section{RESULTS AND DISCUSSION}

This section provides results and discussion of the theoretical review presented in the previous section. The main focus was on distilling the conceptual and methodological challenges for measuring 
resilience. Methods of contextualizing the measurement approaches in the small retail business sector were also discussed in the section.

\subsection{Conceptual challenges for measuring resilience}

Resilience broadly applies to various fields. As such, measuring the concept requires a detailed understanding of what has to be measured. Yet, resilience frameworks scarcely show detailed contextual understanding of resilience (Sturgess, 2016). Furthermore, while there are efforts to quantify resilience in psychology, household level, communities and infrastructure, there are very few straightforward approaches to measuring business resilience. This makes it difficult to measure resilience, particularly in the small retail sector. In most definitions, the adaptive capacity of a system, organization or business is singled out as a critical attribute of resilience. However, Levine (2014) argues that it is difficult to measure adaptive capacity as it comprises financial, technical, cultural and social components among other aspects. According to the Resilience African Network (Sturgess, 2016), resilience must be placed in relation to a particular outcome. This implies that resilience must be specific to context, space and shocks. The argument nullifies the application of generic indicators and attributes of resilience.

\subsection{Methodological challenges}

To date, there are limitations in the methodologies applied in studies related to approaches for resilience measuring (Erol et al., 2010). The reasons for the shortfall are twofold. Firstly, measuring small retail resilience is complex in that it requires a clear understanding of the multifaceted connections of a business and its immediate environment. Secondly, measuring small retail resilience requires a detailed understanding of the inherent attributes of the enterprise, which evolve and contribute to its resilience prowess. It has also been observed that most scholars who focused on business resilience measuring approaches mainly utilized secondary data analysis procedures. For instance, the conceptual models approach to resilience (Gibson et al., 2010), models of resilience measuring (Erol et al., 2010). This has limited their understanding of the practical situations on the ground.
Others utilize qualitative methods only (Demmer et al., 2011; Jackson \& Stoel, 2011). Paradoxically, it is difficult to design generalizable indices for measuring small retail resilience using only qualitative methods. More so, qualitative enquiries normally focus on the external validity of assessment, thus risking drawing unfounded conclusions because of insufficient attention to internal validity. Some studies are more inclined towards quantitative methods due to their statistical value. However, quantitative methods exclude probing questions and interpretation based on explanation, a fact which is important in understanding resilience (Levine, 2014). Given this gap in methodological utilization, Erol et al. (2010), Levine (2014) recommended the use of more intensive methodologies (mixed studies) in order to develop dynamic measurement approaches of resilience. It is also difficult to understand resilience without carrying out longitudinal studies that permit researchers to understand what makes people resilient over time. In light of the above shortcomings, using sequentially mixed qualitative, quantitative approaches and longitudinal studies may assist in the development of better predictors of resilience for small retail businesses.

\subsection{Contextualizing small retail business resilience measuring}

It is vital to note that this paper does not criticize the usefulness of existing approaches to measuring resilience. In fact, it draw lessons from existing approaches in order to find appropriate methods that guide resilience measurement in the small retail businesses sector. Literature reviewed that the main defining aspects of small retail business resilience are the ability to detect, prevent and adapt to threats in a sustainable manner. In this regard, practitioners, policy makers and retail managers who intend to measure resilience must have a clear understanding of small business resilience before attempting to measure the construct.

The approach that entails resilience measuring against the disruptive by Westrum (2006) was considered more comprehensive for use in measuring small retail business resilience. The approach demonstrates that resilience is a function of business ability to detect disruptive threats, 
prevent consequences and adapt (Westrum, 2006). Disruptive events are weighed according to their predictability, potential to disrupt a system and whether the disruption is internal or external. The approach is comprehensive in that it assumed that resilience related actions occur proactively, concurrently or as a response to a disruption that has already happened (Hollnagel et al., 2006). In the context of small retail businesses, the ability to understand the past, present and future relationships between threats and response actions enables effective assessment of resilience prowess at a given time. In the same line of thinking, Hamel and Valikangas (2003) suggest that businesses should focus on continuously anticipating and reacting to deep, secular trends that can permanently damage the earning prowess of the core business. The approach advantageously consists of resilience capacities and characteristics (adaptive capacities, anticipatory and absorptive capacities) that are embedded in other frameworks such as DFID and the continuous process and the 3-Ds resilience frameworks.

Literature review demonstrated that most of the existing approaches to resilience measuring are not appropriate for use in small retail business resilience studies. In this regard, there is a need for future studies to develop simple and custom- ized approaches to resilience measuring that are applicable to small retail businesses. There is also a need for developing diagnostic approaches that assist in assessing resilience levels, as well as monitoring changes in resilience drivers over time. This will reduce the use of generic approaches that are borrowed from other fields.

Identifying idiosyncratic and covariate threats in the broadly informal small retail business sector also enables the development of target oriented preventive and response actions. In line with this view, Sancis and Poler (2014) echoed that it is necessary to understand, assess and analyze the factors that affect enterprise resilience before attempting to take resilience actions. Assessing detection capacities of a business provides a clear picture of area specific threats. Thereafter, customized preventive and adaptive capacities can be aligned to prevailing threats. Although the approach cannot be regarded as a perfect tool for use in resilience measuring, it provides insight into how resilience of small retail businesses can be measured. The abovementioned approach guided the development of a criteria for measuring small retail business resilience (checklist for predicting resilience levels) in a subsequent empirical study informed by this review paper.

\section{CONCLUSION}

The paper reviewed literature related to the approaches for measuring resilience. Resilience is defined in various ways depending on the school of thought and context. However, the most defining aspects of small retail resilience include the ability to detect, prevent and adapt to threats while maintaining sustainability. While the equilibrium concept is core to definitions in psychology and ecology, adaptive and transformative capacities are key in climate and business resilience definitions. Due to these contextual variations, most of the approaches encompass some but not all aspects of resilience. Reviewed frameworks differ in terms of scale, focus, method of analysis and purpose. As such, it is difficult to compare the frameworks or attempt to apply a one size fit all approach. However, there are some similarities in attributes. The strengths of some of the frameworks open the possibility of applying a blended approach in developing resilience measurement approaches for small retail businesses. However, most of the approaches cannot be individually applied to measuring small retail business resilience due to the unique features of the sector. Based on the limitations of applying a one size fit all approach raised in this paper, contextualizing approaches for measuring small retail business resilience that guide practitioners and managers in the sector is desirable. In the subsequent study that followed this review paper, the criteria for measuring small retail business resilience were developed. The criteria were informed by objective and subjective resilience dimensions that reflected practical realities in the small retail sector. The criteria are ideal for use in estimating resilience levels at a particular time, as well as evaluating changes in drivers over time. 


\section{ACKNOWLEDGEMENT}

We would like to acknowledge the National Research Foundation and University of Venda Publication Committee for funding this work.

\section{REFERENCES}

1. Arianoutsou, M., Koukoulas, S., Kazanis, D. (2011). Evaluating postfire forest resilience using GIS and multi-criteria analysis: an example from Cape Sunion National Park, Greece. Environmental Management, 47, 384-397. https:// doi.org/10.1007/s00267-011-9614-7

2. Burgelman, R. A., \& Grove, A. S. (2007). Cross-boundary disruptors: Powerful interindustry entrepreneurial change agents. Strategic Entrepreneurship Journal, 1(3-4), 315-327. https://doi. org/10.1002/sej.27

3. Béné, C. (2013). Towards a Quantifiable Measure of Resilience (IDS Working Paper 434). Brighton: Institute of Development Studies. Retrieved from http://opendocs. ids.ac.uk/opendocs/bitstream/ handle/123456789/2990/Wp434.pd f;jsessionid=B69E2EEA86FED460E 4E1B66668402D71? sequence $=1$

4. Byrom, DJ. G. W. (2003). Strategic alternatives for small retail businesses in rural areas. Management Research News, 26(7), 33-49. https://doi. org/10.1108/01409170310783574

5. Dalziell, E. P., \& McManus, S. T. (2004). Resilience, Vulnerability, Adaptive Capacity: Implicationsfor System Performance. Paper presented at International Forum for Engineering Decision Making (IFED) Stoos, Switzerland.

6. Demmer, W. A., Vickery, S. K., \& Calantone, R. (2011). Engendering resilience in small- and mediumsized enterprises (SMEs): a case study of Demmer Corporation. International Journal of Production Research, 49(18), 5395-5413. http:// dx.doi.org/10.1080/00207543.2011 .563903

7. DFID (2011). Defining Disaster Resilience: A DFID Approach Paper. London: DFID.

8. Ehlers, T., \& Lazenby, K. (2007).
Strategic management: South Africa concepts and cases. Pretoria: Van Schaik.

9. Egbu, C. O., Hari, S., \& Renukappa, S. H. (2005). Knowledge management for sustainable competiveness in small and medium surveying practices. Structural Survey, 23(1), 7-21. https://doi. org/10.1108/02630800510586871

10. El Sawy, O. A., \& Pereira, F. (2013). Business Modelling in the Dynamic Digital Space: An Ecosystem Approach. Springer Heidelberg. New York: Dordrecht London.

11. Erol, O., Henry, D., Sauser, B., \& Mansouri, M. (2010). Perspectives on Measuring Enterprise Resilience. Proceedings of 4th Annual IEEE International Systems Conference, San Diego.

12. Erkip, F., Kızılgun, O., \& Akinci, G. M. (2014). Retailers' resilience strategies and their impacts on urban spaces in Turkey. Cities, 36, 112-120. https://doi.org/10.1016/j. cities.2012.12.003

13. FAO (2012). Resilience Index Measurement and Analysis (RIMA). Retrieved from www.fao.org/3/ ai4102e.pdf (accessed on February $25,2018)$

14. Fatoki, O., \& Garwe, D. (2010). Obstacles to the growth of new SMEs in South Africa: A principal component analysis approach. African Journal of Business Management, 4(5), 729-738. Retrieved from https://www.researchgate.net/ publication/267553799_Obstacles_to_the_growth_of_new_ SMEs_in_South_Africa_A_principal_component_analysis_approach

15. Frankenberger, T., \& Nelson, $\mathrm{S}$. (2013). Background Paper for the Expert Consultation on Resilience Measurement for Food Security. FSIN.
16. Gibson, C. A., \& Tarrant, M. (2010). A "conceptual models" approach to resilience. International Journal of Production Research, 25(2), 6-12. Retrieved from https://eprints.qut.edu. au/38838/

17. Hamel, G., \& Valikangas, L. (2003). The quest for resilience. Harvard Business Review, 81, 52-65. Retrieved from https://www.ncbi. nlm.nih.gov/pubmed/12964393

18. Helaakoski, H., Iskanius, P., \& Peltomaa, I. (2007). Agentbased architecture for virtual enterprises to support agility. In L. Camarinha-Matos et al. (Eds.), IFIP International Federation for Information Processing, Volume 243, establishing the foundation of collaborative networks (pp. 299306). Boston: Springer.

19. Haimes, Y. Y., Crowther, K., \& Horowitz, B. M. (2008). Homeland security preparedness: Balancing protection with resilience in emergent systems. Systems Engineering, 11(4), 287308. https://doi.org/10.1002/ sys. 20101

20. Hollnagel, E., Woods, D. D., \& Levesson, N. (2006). Resilience engineering: Concepts and precepts. Hampshire: Ashgate.

21. Hughes, K. A., \& Fuller, R. (2013). Disaster Risk Reduction Programming in Ethiopia's Somali Region - Effectiveness Review: Full Technical Report. Oxfam GB.

22. Hu, Y., Li, J., \& Holloway, E. L. (2008). Towards modeling of resilience dynamics in manufacturing enterprises: literature review and problem formulation. Paper presented at Fourth IEEE Conference on Automation Science and Engineering, Washington DC: IEEE. 
23. Jackson, V. P., \& Stoel, L. (2011). A qualitative examination of decoupling, recoupling and organizational survival of rural retailers. Qualitative Market Research: An International Journal, 14(4), 410-428. https://doi. org/10.1108/13522751111163236

24. Kanter, D., \& Say, A. I. (2015). Measuring organizational resilience: a scale development. Journal of Business Economics and Finance, 4(3), 2146-7943. Retrieved from https://www. researchgate.net/publication/283785352_Measuring_Organizational_Resilience_A_Scale_ Development

25. International Labour Organization (ILO). (2006). A Local Economic Development Manual for China. ILO, Geneva.

26. Ingirige, B., Proverbs, D., \& Jones, K. G. (2008). Investigating $S M E$ Resilience and their Adaptive Capacities to Extreme Weather Events: A Literature Review and Synthesis (CIB W89). Building Education and Research (BEAR), Sri Lanka.

27. Ligthelm, A. (2006). Size and estimate of the informal sector in South Africa. Southern African Business Review, 10(2), 32-52. Retrieved from https://journals. co.za/content/sabr/10/2/EJC92832

28. Levine, S. (2014). Assessing resilience: why quantification misses the point. Humanitarian Policy Group, Overseas Development Institute. Retrieved from http://www.odi.org/sites/odi. org.uk/files/odi-assets/publications-opinion-files/9049.pdf

29. Levy, M., Loebbecke, C., \& Powell, P. (2003). SMEs, cooperation and knowledge sharing: the role of information system. European Journal of Information System, 12(1), 3-17. https://doi.org/10.1057/ palgrave.ejis.3000439

30. Madzivhandila, T. S. (2014). Rural Entrepreneurship as a strategy for rural development in South Africa. In Prospects, opportunities and challenges. South African Association Chapter (pp. 292-401).

31. Maxwell, D., Constas, M., Frankenberger, T., Klaus, D., \&
Mock, M. (2015). Qualitative Data and Subjective Indicators for Resilience Measurement. Resilience Measurement Technical Working Group. Technical Series No. 4. Rome: Food Security Information Network. Retrieved from http:// www.fsincop.net/fileadmin/ user_upload/fsin/docs/resources/ FSIN_TechnicalSeries_4.pdf

32. Muller, N. J., Besser, T. L., Gaskill, L. R., \& Sapp, S. G. (2003). Community and managerial predictors of performance in small rural US retail and service firms. Journal of Retailing and Consumer Services, 10(1), 215-230. https://doi.org/10.1016/S09696989(02)00012-7

33. Oxfam (2013, August). A Multidimensional Approach for Measuring Resilience (Oxfam GB Working Paper Oxfam GB).

34. Rachidi, M. F. (2014). Examination of challenges faced by youth-owned small medium micro-enterprises in Limpopo of South Africa. Mediterranean Journal of Social Sciences, 5(27), 1258-1263. Retrieved from http://www.mcser.org/journal/ index.php/mjss/article/viewFile/5204/5021

35. Replacis (2011). Retail Planning for Cities Sustainability (Final report).

36. Rose A., \& Liao, S. (2005). Modeling regional economic resilience to disasters: a computable general equilibrium analysis of water service disruptions. Journal of Regional Science, 45(1), 75-112. https:// doi.org/10.1111/j.00224146.2005.00365.x

37. Sanchis, R., \& Poler, P. (2014). Enterprise resilience assessment: a categorization framework of disruptions. Dirección y Organización, 12(54), 45-53. Retrieved from https://riunet.upv. es/handle/10251/58456

38. Sanyal, S., \& Hisami, M. W. (2015). Factors affecting entrepreneurial aspirations among Oman youth: An empirical study. International Journal of Business and Administration Research Review, 2(9), 1-14. Retrieved from https://www.researchgate.net/ publication/278238579_Factors_ Affecting_Entrepreneurial_Aspirations_Among_Omani_Youth_ An_Empirical_Study

39. SEDA (2007). Review of trends on entrepreneurship and the contribution of small enterprises to the economy of South Africa, 20002006. Pretoria: Small Enterprises Development Agency.

40. Sheffi, Y., \& Rice, J. B. (2005). A supply chain view of the resilient enterprise. MIT Sloan Management Review, 47(1), 41-48. Retrieved from https://search.proquest. com/openview/ab02ef85c434 66ea1085994bc7340615/1?pqorigsite $=$ gscholar $\& \mathrm{cbl}=26142$

41. Starr, R., Newfrock, J., \& Delurey, M. (2003). Enterprise resilience: managing risk in the Networked economy. Strategy business, 30, 1-10. Retrieved from https:// www.researchgate.net/publication/285914987_Enterprise_resilience_Managing_risk_in_the_networked_economy

42. Sterling, S. (2011). Encouraging resilience within SMEs: The Cabinet Office's proposed approach. Journal of Business Continuity \& Emergency Planning, 5(2), 128-139. Retrieved from https://www.ncbi. nlm.nih.gov/pubmed/21835751

43. Sturgess, P. (2016). Measuring resilience (Thematic Summary). Retrieved from https://www. gov.uk/dfid-research-outputs/ measuring-resilience (accessed on August 12, 2017).

44. Sullivan-Taylor, B., \& Wilson, D. C. (2009). Managing the Threat of Terrorism in British Travel and Leisure Organizations. Organization Studies, 30, 251-276. https://doi.org/10.1177\%2F0170840608101480

45. Timmons, J. A., \& Spinelli, S. (2009). New venture creation: entrepreneurship for the 21st century (8th ed.). New York, NY: McGraw-Hill Irvin.

46. UNDP (2014). Understanding Community Resilience: Findings from Community-Based Resilience Analysis (CoBRA) Assessments: Marsabit, Turkana and Kajiado 
counties, Kenya and Karamoja sub-region. Retrieved from http:// www.undp.org/content/dam/undp/ library/Environment\%20and\%20 Energy/sustainable\%20land\%20 management/CoBRA/CoBRA_Assessments_Report.pdf

47. USAID (2013, October). Community Resilience: Conceptual Framework and Measurement Feed the Future Learning Agenda.

48. Van Scheers, L. (2010). Challenges of small family groceries shops in South Africa. World Journal of Entrepreneurship Management and Sustainable Development, 6(3), 221-231. https://doi. org/10.1108/20425961201000017

49. Vanessa, P., \& Jackson, L. S. (2011). A qualitative examination of decoupling, recoupling and Organizational survival of rural retailers. Qualitative Market Research: An International Journal, 14(4), 410-428. https://doi. org/10.1108/13522751111163236

50. Vaitla, B., Tesfay, G., Rounseville, M., \& Maxwe, D. (2012, October) Resilience and Livelihoods Change in Tigray, Ethiopia. Feinstein International Center.

51. Wreathall, J. (2006). Developing Models for Measuring Resilience. Dublin: Ohio.

52. Westrum, R. (2006). A typology of resilience situations. In E. Hollnagel, D. D. Woods \& N. Leveson (Eds.), Resilience engineering: concepts and precepts. Aldershot, UK: Ashgate Press.
53. Woodward, D., Ligthelm, A., Guimaraes, P., \& Rolfe, B. (2011). The viability of informal microenterprise in South Africa. Journal of Developmental Entrepreneurship, 16(1), 6586. https://doi.org/10.1142/ S1084946711001719

54. Woods, D. D., \& Hollnagel, E. (2006). Prologue: resilience engineering concepts. In E. Hollnagel, D. D. Woods \& N. Leveson (Eds.), Resilience engineering: concepts and precepts. Aldershot, UK: Ashgate Press.

55. Zobel, C. W. (2011). Representing perceived tradeoffs in defining disaster resilience. Decision Support Systems, 50(2), 394403. https://doi.org/10.1016/j. dss.2010.10.001 